\title{
Kandungan Protein, Lemak, Dan Karbohidrat Pada Biomassa Spirulina platensis Yang Kultivasi Pada Media Berbasis Kotoran Burung Puyuh
}

\section{Protein, Fat, and Carbohydrate Content in Spirulina platensis Biomass Cultivated on Quail Manure Based Media}

\author{
Shokimun Mega Samudera ${ }^{1)}$, Tatang Sopandi ${ }^{2)}$ \\ ${ }^{1,2}$ Prodi Biologi FST Universitas PGRI Adi Buana Surabaya. \\ Email: Shokimun@,gmail.com ${ }^{1)}$ Tatang_sopandi@yahoo.co.id ${ }^{2}$
}

\begin{abstract}
Abstrak
Komponen penyediaan media nutrisi merupakan biaya tinggi dalam kultivasi Spirulina platensis. Pencarian media sumber nutrisi perlu dilakukan dalam kultivasi S.platensis untuk menekan biaya produksi dan meningkatkan pendapatan. Penelitian ini bertujuan mengevaluasi kandungan protein, lemak dan karbohidrat biomassa $S$. platensis yang dikultivasi pada media kotoran puyuh. Penelitian dilakukan pada bulan Maret sampai Juni 2020 menggunakan metode eksperimental dengan Rancangan Acak Lengkap (RAL) yang terdiri atas 4 perlakuan dan 6 kali ulangan. Konsentrasi kotoran puyuh yang digunakan sebagai media sumber nutrisi pada penelitian ini terdiri 50, 100 dan $150 \mathrm{~g} / \mathrm{L}$ serta media Zarrouk digunakan sebagai kontrol atau media standar. Hasil penelitian menujukkan bahwa konsentrasi kotoran puyuh berpengaruh signifkan $(\mathrm{P}<0.05)$ terhadap kandungan protein, lemak, dan karbohidrat biomassa $S$ platensis. Konsentrasi yang optimum penggunaan kotoran puyuh sebagai media kultivasi S.plantesis adalah $100 \mathrm{~g} / \mathrm{l}$.
\end{abstract}

Kata kunci : Spirulina platensis, kotoran puyuh, protein, karbohidrat, lemak

\begin{abstract}
The components of providing nutritional media are a high cost in the cultivation of Spirulina platensis. It is necessary to search for media sources of nutrition in S.platensis cultivation to reduce production costs and increase income. This study aimed to evaluate the protein, fat and carbohydrate content of S. platensis biomass cultivated in quail manure media. The study was conducted from March to June 2020 using an experimental method with a completely randomized design (CRD) consisting of 4 treatments and 6 replications. The concentrations of quail manure used as a source of nutrition in this study consisted of 50, 100 and $150 \mathrm{~g} / \mathrm{L}$ and Zarrouk's medium was used as a control or standard media. The results showed that the concentration of quail manure had a significant effect $(P<0.05)$ on the protein, fat, and carbohydrate content of $S$ platensis biomass. The optimum concentration for using quail dung as a cultivation medium for S.plantesis is $100 \mathrm{~g} / \mathrm{L}$.
\end{abstract}

Keywords: Spirulina platensis, quail manure, protein, carbohydrates, fat

\section{PENDAHULUAN}

Spirulina platensis merupakan salah satu pakan alami yang sudah dimanfaatkan sebagai pakan alami untuk budidaya organisme laut seperti larva oyster, rotifer, albalone, kerang mutiara, kakap, kerapu, dan udang (Isnansetyo dan Kurniastuty, 1995). S. platensis memiliki $60-71 \%$ kandungan protein, $8 \%$ kandungan lemak, 16\% karbohidrat, $\quad 1.6 \%$ klorofil -a, $18 \%$ pikosianin, $17 \%$ betakarotein, 20-30\% vitamin dan asam linoleat. Kandungan pigmen karetonoid yang tinggi sebagai sumber potassium, krom, kalsium, besi, tembaga, magnesium, fosfor, sodium, seng, dan selenium juga terkandung dalam $S$. platensis. (Suminto, 2009).

Pigmen biru fikosianin yang terkandung pada berat kering $S$ platensis sekitar 20\%. Supplai nitrogen sangat berpengaruh terhadap kandungan fikosianin dalam $S$ platensis. Fikosianin banyak digunakan sebagai kosmetika, obat-obatan, dan pewarna alami. Protein kompleks pada Fikosianin S platensis mampu meningkatkan sistem kekebalan tubuh, antioksidan dan bersifat anti kanker (Kozlenko dan Henso, 1998).

Spirulina platensis berpotensi untuk diproduksi secara komersial dan digunakan 
sebagai pangan dan pakan (Holman and Malau-Aduli, 2013; Sopandi et al., 2020) karena kaya protein, lemak, karbohidrate dan komponen penting lainnya (Kerswell, 2006; Sherwood et al., 2010) seperti klorofil (Moraes et al., 2011) dan asam amino (Avila-Leon et al., 2012). Kandungan nutrisi dalam biomassa $S$. platensis telah menarik pasar industri pakan ternak. Sekitar separuh dari produksi biomassa S.plantesis telah digunakan sebagai pakan ternak dan ikan (Holman dan Malau-Aduli, 2013).

Spirulina platensis mampunyai daya adaptasi tinggi terhadap berbagai kondisi nutrisi (Sopandi et al., 2020), namun untuk menghasilkan biomassa $S$. platensis yang mempunyai komponen biokimia seperti protein, karbohidrat dan diperlukan media nutrisi yang mempunyai kualitas baik yang secara umum menggunakan Zarrouk dan Walne sebagai media penyedia nutrisi. Tingginya biaya yang berasal dari komponen penyediaan media nutrisi pada budidaya $S$. platensis telah mendorong para peneliti untuk mencari media alternatif untuk meminimalkan biaya produksi dan meningkatkan pendapatan (Sopandi et al., 2020).

Limbah peternakan puyuh berupa kotoran berpotensi untuk digunakan sebagai media penyedia nutrisi untuk S.platensis. Kotoran puyuh dimanfaatkan sebagai pupuk tanaman oleh petani. Beberapa peneliti telah melaporkan penggunaan kotoran kambing (Sopandi et al., 2020), babi (Olguin et al., 2001) dan ayam (Iyoyo et al., 2010) sebagai media penyedia nutrisi untuk kultivasi S.platensis. Kotoran ayam dilaporkan merupakan sumber nitrogen yang murah untuk kultivasi S.platensis (Iyoyo et al., 2010). Namun penelitian mengenai pemanfaatan kotoran puyuh sebagai media penyedia nutrisi belum pernah dilaporkan. Penelitian ini bertujuan mengevaluasi kandungan protein, lemak dan karbohidrat biomassa S.platensis yang dikultivasi pada media yang berbasis kotoran puyuh.

\section{METODOLOGI PENELITIAN}

Penelitian telah dilakukan secara eksperimental menggunakan rancangan percobaan acak lengkap dengan 4 perlakuan konsentrasi kotoran puyuh dalam media kultivasi yang masing-masing diulang perlakuan dan 6 kali ulangan. Perlakuan konsentrasi kotoran puyuh dalam media terdiri adari A $0 \mathrm{~g} / \mathrm{l}$ (media Zarrouk) sebagai kontrol), $50 \mathrm{~g} / 1,100 \mathrm{~g} / 1$, dan $150 \mathrm{~g} / 1$.

\section{Penyiapan media kotoran puyuh}

Kotoran puyuh yang diperoleh dari peternakan puyuh di daerah Pare, Kediri dikeringkan dengan sinar matahari selama 3 hari. Setelah kering, kotoran puyuh ditumbuh dan diayak untuk memperoleh bentuk tepung. Sebanyak $1500 \mathrm{~g}$ tepung kotoran puyuh dibagi menjadi 3 bagian masing-masing dicampurkan 4,5 1 air distalata. Setelah homogen, masing-masing dibagi 6 dan dimasukan ke dalam labu Erlenmeyer ukuran $250 \mathrm{ml}$. Media Zarrouk's dibuat sesuai dengan petunjuk (Zarrouk, 1966) digunakan sebagai media control tanpa penggunaaan kotoran puyuh. Semua media disterilisasi dalam autoclave pada suhu $121^{\circ} \mathrm{C}$ tekanan $1 \mathrm{~atm}$ selama 15 menit. Hasil sterilisasi difiltrasi menggunakan kertas saring secara aseptik.

\section{Kultivasi Spirulina platensis}

Semua media yang berisi kotoran puyuh yang telah disterilisasi dan didinginkan, selanjutnya disaring dengan kertas saring secara aseptik. Masing-masing filtrat diinokulasi $250 \mathrm{ml}$ bibit $S$. platensis. Kultivasi $S$. platensis dilakukan selama 10 hari pada suhu $25-35^{\circ} \mathrm{C}$, pH 9.0-9.5, intesitas cahaya 5000 lux (Benetech GM 1020 illuminance meter) dan diberi aerasi dari aerator aquarium (SONIC P-125, 85 L/min, $0.04 \mathrm{MPa})$.

\section{Pengamatan pertumbuhan Spirulina platensis}

Pertumbuhan $S$ platensis diamati setiap 24 jam selama 10 hari menggunakan Spektrofotometer pada panjang gelombang $680 \mathrm{~nm}$ sesuai dengan petunjuk Yap et al. (2018). Sebanyak $5 \mathrm{ml}$ media kultur 
S.platensis disaring dengan kertas. Residu dicuci 2 kali dengan air distilata dan dikeringkan pada suhu $80^{\circ} \mathrm{C}$ selama 12 jam dalam pengering kabinet. Residu kering dilarutkan ulang dalam $5 \mathrm{ml}$ air distilata, dimasukan ke dalam kuvet kemudian obsorbansinya diukur pada $680 \mathrm{~nm}$. Biomassa kering S.platensis dihitung dengan persamaan

$Y_{\text {biomass }}=0.8279 X_{\mathrm{OD} 680}+0,038$.

regresi

\section{Panen Spirulina platensis}

Panen biomassa S.platensis pada hari ke-10 kultivasi yang dilakukan dengan memisahkan $S$. platensis dari media menggunakan jaring plannet ukuran diameter $50 \mathrm{~nm}$. Setelah dicuci 2 kali dengan air distilata, berat basah $S$ platensis ditimbang selanjutnya dikeringkan dalam pengering kabinet pada suhu $80^{\circ} \mathrm{C}$ selama 12 jam dan setelah kering ditimbang ulang.

\section{Analisis proksimat}

Analisis proksimat kadar protein, lemak dan karbohidrat biomassa S.platensis masing-masing menggunakan metode Kjeldahl (SNI 01-2354.4-2006, asam fenol sulfat (Apriantono, 1998) dan metode Soxhlet (SNI 01-2891-1992).

\section{Analisis statistika}

Data hasil pengamatan biomassa serta kandungan protein, lemak dan karbohidrat biomassa S.platensis dianalisis menggunakan analisis varian satu arah dengan taraf signifikansi 0.05. Uji lanjut untuk mengetahui letak perbedaan antar perlakuan dilakukan menggunakan uji beda nyata terkecil pada taraf signifikasi 0,05 .

\section{HASIL PENELITIAN}

\section{Pertumbuhan Spirulina platensis}

Hasil pengamatan pertumbuhan $S$ platensis pada berbagai konsentrasi kotoran burung puyuh dalam media kultivasi disajikan pada Gambar 1. Pertumbuhan S.platensis yang dikultitvasi dalam media Zarouk lebih tinggi dibandingkan dengan media kultivasi yang menggunakan kotoran puyuh pada berbagai konsentrasi. Pertumbuhan S.plantesis yang dikultivasi dalam media kotoran puyuh dengan konsentrasi $150 \mathrm{~g} / 1$ lebih tinggi dibandingkan dengan $100 \mathrm{~g} / \mathrm{l}$ dan $50 \mathrm{~g} / \mathrm{l}$. Gambar 1 juga memperlihatkan bahwa pertumbuhan S.platensis yang dikultivasi pada media kotoran puyuh dengan konsentrasi $\quad 100 \quad \mathrm{~g} / \mathrm{l}$ lebih tinggi dibandingkan dengan $50 \mathrm{~g} / 1$.

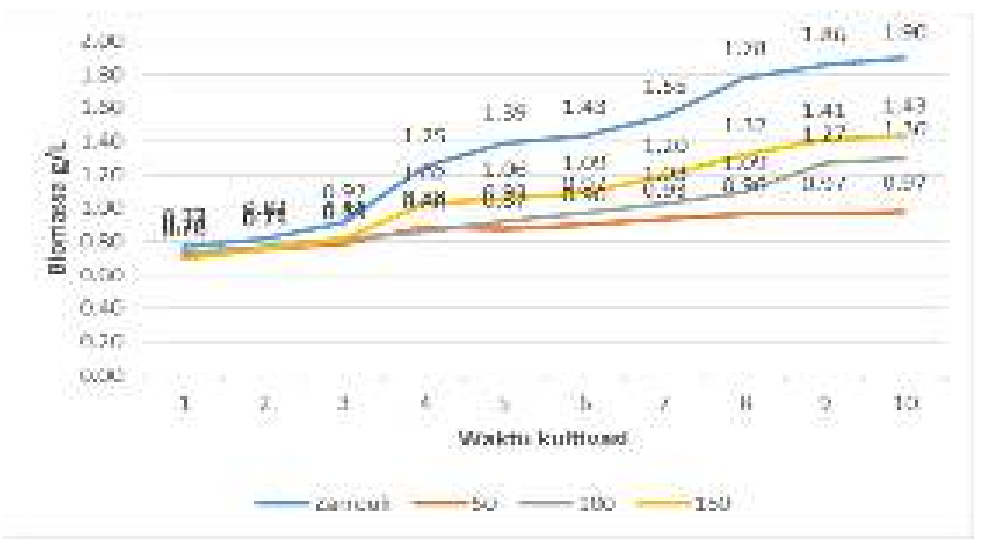

Gambar 1. Pertumbuhan S. Pantensis yang dikultivasi dalam media Zarrouk dan kotoran puyuh. 


\section{Kandungan protein Spirulina platensis}

Hasil analisis kandungan protein pada biomassa S.platensis yang dikultivasi pada media Zarrouk dan berbagai media kotoran puyuh disajikan pada Gambar 2. Hasil penelitian menunjukkan bahwa kandungan protein biomassa S.platensis yang dikultivasi pada media Zarrouk signifikan $\quad(\mathrm{P}<0,05) \quad$ lebih tinggi dibandingkan dengan kandungan protein biomassa S.platensis yang dikultivasi pada media kotoran ayam dengan konsentrasi 50, 100 dan $150 \mathrm{~g} / \mathrm{l}$. Gambar 2 juga memperlihatkan bahwa kandungan protein biomassa S.platensis yang dikultivasi pada media kotoran ayam $150 \mathrm{~g} / \mathrm{l}$ tidak berbeda signifikan $(\mathrm{P}>0.05)$

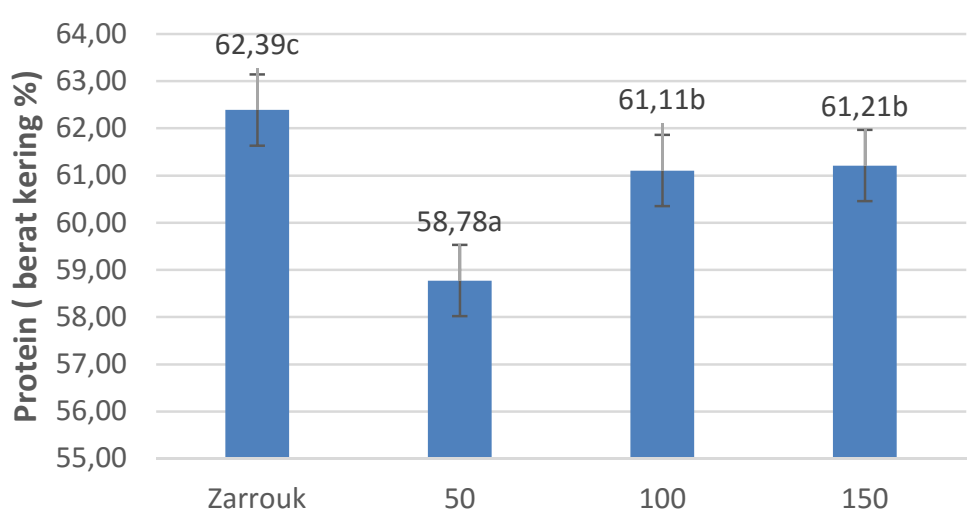

Zarrouk dan konsentrasi kotoran burung puyuh (g/L)

Gambar 2. Kandungan protein biomassa S.platensis yang dikultivasi dalam media Zarrouk dan media kotoran puyuh

\section{Kandungan lemak $S$ platensis}

Hasil analisis kandungan lemak biomassa $S$. platensis yang dikultivasi pada media Zarrouk, dan media kotoran puyuh dengan beberapa konsentrasi disajikan Gambar 3. Kandungan lemak biomassa S.platensis yang dikultivasi pada media kotoran ayam dengan konsentrasi $150 \mathrm{~g} / 1$ signifikan $(\mathrm{P}<0,05)$ dibandingkan dengan media Zarrouk, $100 \mathrm{~g} / 1$ dan $50 \mathrm{~g} / 1$ kotoran puyuh. Namun demikian tidak terdapat perbedaan yang signifikan $(\mathrm{P}>0,05)$ antara kandungan lemak S.platensis yang dikultivasi pada media Zarrouk, $100 \mathrm{~g} / \mathrm{l}$ dan $50 \mathrm{~g} / 1$ kotoran puyuh.

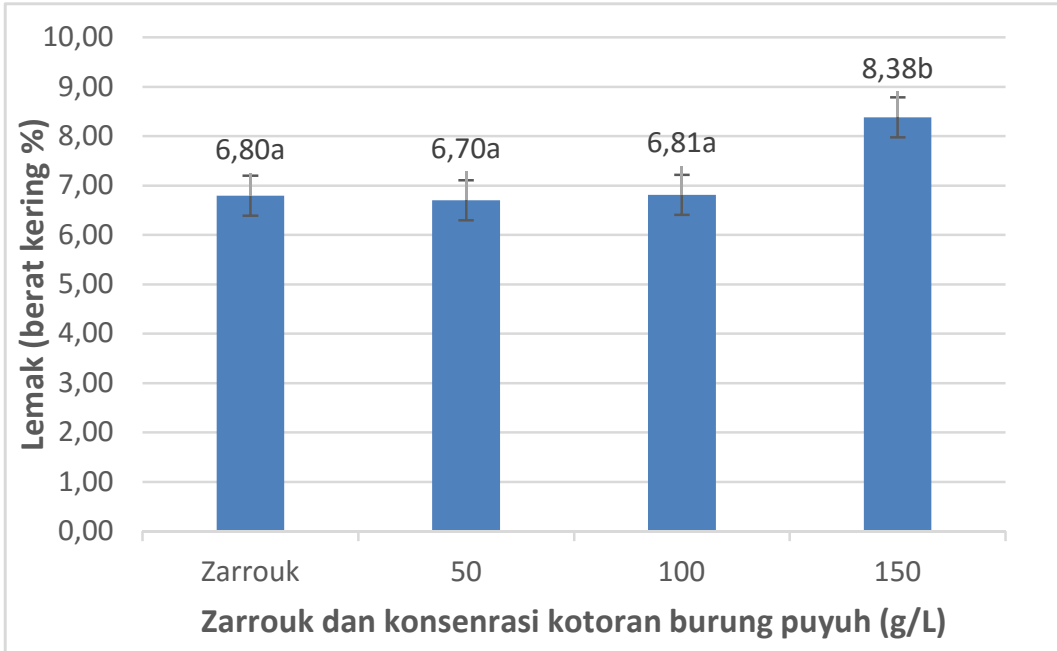

Gambar 3. Kandungan lemak biomassa S.platensis yang dikultivasi pada media Zarrouk dan media kotoran burung puyuh. 


\section{Kandungan karbohidrat Spirulina platensis}

Hasil analisis kandungan karbohidrat S. platensis yang dikultivasi pada media Zarrouk dan media kotoran puyuh disajikan pada Gambar 4. Hasil analisis menunjukkan bahwa kandungan karbohidrat biomassa S.platensis yang dikultivasi pada kotoran ayam dengan konsentrasi $50 \mathrm{~g} / 1$ signifikan
$(\mathrm{P}<0,05)$ lebih tinggi dibandingkan dengan media Zarrouk serta media kotoran puyuh dengan konsentrasi 100 dan 150 g/l. Namun tidak terdapat perbedaan yang signifikan antara kandungan karbohidrat biomassa S.platensis yang dikultivasi pada media Zarrouk serta kotoran puyuh 100 dan 150 $\mathrm{g} / \mathrm{l}$.

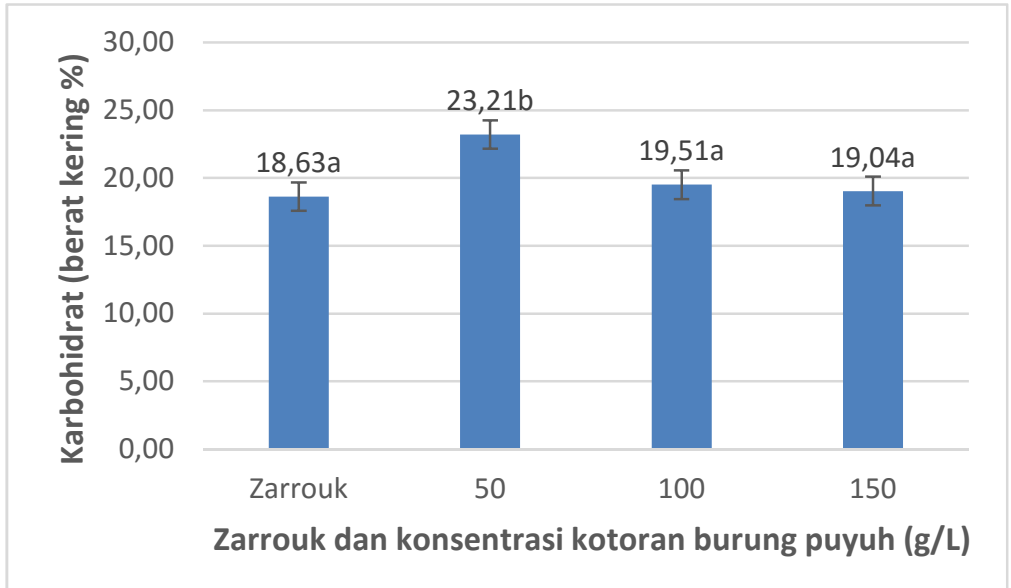

Gambar 4. Kandungan karbohidrat biomassa S.platensis yang dikultivasi pada media Zarrouk dan media kotoran puyuh.

\section{PEMBAHASAN}

\section{Pertumbuhan Spirulina platensis}

Hasil penelitian menunjukkan bahwa pertumbuhan S.platensis selama 3 hari pertama merupakan fase lag yaitu tahap penyesuaian diri terhadap lingkungan (Hariyati, 2008). Namun pertumbuhan S.platensis pada media Zarouk lebih tinggi dibandingkan pada media kotoran puyuh. Setelah fase lag, pertumbuhan S.platensis meningkat yaitu pada kari ke-4 sampai hari ke 9 yang merupakan fase eksponensial. Pertumbuhan S.platensis mengalami puncaknya pada hari ke-10 dan memasuki fase stationer yang ditandai dengan kepadatan yang tinggi. Perbadaan pertumbuhan $S$ platensis antar media kultivasi dipengaruhi oleh dipengaruhi oleh kandungan nutrisi serta faktor lingkungan yang mendukung pertumbuhan $S$ platensis seperti $\mathrm{pH}$, salinitas, oksigen, dan suhu (Utomo et al., 2005).

\section{Kandungan protein}

Kandungan protein yang tinggi pada biomassa S.platensis yang dikultivasi dalam $100 \mathrm{~g} / 1$ dan $150 \mathrm{~g} / 1$ dibandingkan dengan 50 $\mathrm{g} / 1$ kotoran puyuh menunjukkan bahwa nutrisi yang tersedia media kultivasi 100 dan $150 \mathrm{~g} / 1$ kotoran puyuh lebih tinggi dan dapat menyedia nutrisi untuk memenuhi kebutuhan S. platensis. Kandungan protein biomassa S.platensis yang dikultivasi pada media Zarrouk yang lebih tinggi dibandingkan dengan media kotoran burung puyuh diduga karena unsur nitrogen yang tersedia lebih tinggi pada media Zarrouk. Hal ini sesuai dengan Sopandi et al (2020) yang melaporkan bahwa rendahnya konsentrasi nitrogen terutama nitrat dapat menjadi penyebab kandungan protein biomassa $S$ platensis rendah. Zhu et al. (2015) juga melaporkan bahwa penurunan kadar protein disebabkan oleh terbatasnya ketersediaan nitrogen dalam media kultivasi. 
Penyusunan senyawa protein dalam sel sangat dipengaruhi oleh kandungan nitrogen dan fosfor, sehingga jika kekurangan kedua unsur tersebut dapat menyebabkan sel-sel mengalami penurunan kandungan protein yang pada diikuti oleh degradasi komponen sel yang berkaitan dengan sintesis protein. Penghambatan sintesis protein dan sintesis karbohidrat dipengaruhi oleh konsentrasi fosfor dan nitrogen (Chrismadha, 2006)

\section{Kandungan lemak}

Kandungan lemak biomassa S.platensis yang dikultvasi dalam media kotoran puyuh dengan konsentrasi $150 \mathrm{~g} / \mathrm{l}$ lebih tinggi dibandingkan dengan Zarrouk dan kotoran burung $50 \mathrm{~g} / 1$ dan $100 \mathrm{~g} / 1$ diduga karena kepekatan media kultivasi pada konsentrasi $150 \mathrm{~g} / \mathrm{l}$ sehingga penyebaran cahaya tidak menyebar merata ke seluruh sel S.platensis dan menghambat proses fotosintesis yang pada giliranya sintesis lemak. Hal ini sesuai dengan penelitian Hirano et al (2008) yang melaporkan bahwa kultivasi $S$ platensis keadaan gelap dalam beberapa hari dapat meningkatkan kandungan lemak.

\section{Kandungan karbohidrat}

Hasil penelitian menunjukkan kadar karbohidrat biomassa $S$. platensis yang dikultivasi pada media Zarrouk lebih rendah dibandingkan dengan kadar karbohidrat $S$ platensis yang dikultivasi pada media kotoran puyuh pada konsentrasi $50 \mathrm{~g} / \mathrm{l}$. Hal ini diduga karena pengaruh sumber nitrogen yang rendah. Kandungan nitrogen yang rendah dalam media dapat menurunkan sintesis protein dan meningkatkan sinstesis karbohidrat Susano et al (2010) melaporkan bahwa pada kondisi nitrogen yang rendah kandungan protein biomassa S.platensis menurun dan dapat mencapat $20 \%$ sementara karbohidrat dapat mencapai $65 \%$. Sebaliknya jika kandungan protein sekitar $50 \%$ maka kandungan karbohidrat berkisar antara $23 \%$.

\section{SIMPULAN DAN SARAN}

Penelitian ini menyimpulkan bahwa kotoran puyuh dapat digunakan sebagai media sumber nutrisi untuk kultivasi $S$. platensis. Konsentrasi kotoran puyuh yang optimum sebagai media kultivasi $S$. platensis adalah $100 \mathrm{~g} / \mathrm{L}$. Konsentrasi kotoran puyuh sama atau kurang dari $50 \mathrm{~g} / \mathrm{L}$ dalam media kultivasi dapat menyebabkan penurunan produktivitas $S$. platensis. Optimalisasi kondisi lingkungan seperti suhu, aerasi dan cahaya perlu diteliti lebih lanjut untuk memaksimalkan produktivitas S.platensis yang dikultivasi pada kotoran puyuh.

\section{DAFTAR PUSTAKA}

Apriantono, A. 1988. Analisis pangan. Bandung: Institut Teknologi Bandung.

Avila-Leon I, Matsudo MC, Sato S and Carvalho JCM. 2012. Arthospira platensis biomass with high protein content cultivated in continuous process using urea as nitrogen sources. J. Appl. Microbiol. 112(6):1084-94.

Fogg, I. Nyoman K. 1998. Spirulina: Ganggang Penggempur Aneka Penyakit.Kanisius. Yogyakarta.

Hariyati, R.,. 2008. Pertumbuhan dan Biomassa Spirulina sp Dalam Skala Laboratoris. Laboratorium Ekologi dan Biosistematik Fakultas Matematika dan IPA Universitas Diponegoro.

Holman BWB and Malau-Aduli AEO. 2013.Spirulina as a livestock supplement and animal feed. Review Article. J. Anim. Physiol. Anim. Nutr. 97: 615-623.

Iyoyo GD, Guocheng D and Chen J, 2010. Poultry manure Digestate Enhancement of Chlorella vulgaris Biomass under Mixotrophic Condition for Biofuel Production. J. Microbial. Biochem. Technol. 2: 051-057.

Kerswell AP,. 2006. Global biodiversity patterns of benthic marine algae. Ecol. 
87(10): 2479-2488.

Marres. 1977. Oil accumulation is controlled by carbon precursor supply for fatty acid synthesis in Chlamydomonas reinhardtii. Plant Cell Physiol. 53(8):1380-1390. http://dx.doi.org/10.1093/pcp/pcs082

Olguin EJ, Galicia S, Angulo-Guerrero O and Hernandez E, 2001. The effect of low light flux and nitrogen deficiency on the chemical composition of Spirulina sp. (Arthrospire) grown on digested pig waste. Bioresour. Tech. 77: 19-24.

Pratiwi M, 2007. Nitrogen-assimilating enzymes in land plants and algae: phylogenic and physiological perspectives. Physiol. Plant. 116: 111.

Raoof J,. 2005. Poultry manure Digestate Enhancement of Chlorella vulgaris Biomass under Mixotrophic Condition for Biofuel Production. J. Microbial. Biochem. Technol. 2: 051-057. http://dx.doi.org/10.4172/19485948.1000023

Chrismadha. 2006. Growth and Reproductive Strategies of Freshwater

Sari.l, 2004. Prediktif pemodelan produksi biomassa oleh Spirulina platensis sebagai fungsi konsentrasi nitrat dan $\mathrm{NaCl}$. Biores. Tech. 100: 1847-1851.

Sheehan. 1998. A Review: Microalgae and Their Applications in CO 2 Capture and Renewable Energy. Aerosol Air Qual. Res. 15: 712-742. http://dx.doi.org/10.4209/aaqr.2014.1 $\underline{1.0299}$

Moraes CC, Sala L, Cerveira GP and Kalil SJ. 2011. C-Phycocyanin Extraction from Spirulina platensis Wet Biomass. Braz. J. Chem. Eng. 1: 45- 49.
Sherwood AR, Kurihara A, Conklin KY, Sauvage T and Presting GG, 2010. The Hawaiian Rhodophyta Biodiversity Survey (2006-2010) a summary of principal findings. BMC Plant Biol. 10(1): 258.

Sopandi,T., Rohmah, S and Agustina, S.A.T. 2020. Biomass and nutrient composition of Spirulina platensis grown in goat manure media. Asian Journal of Agricuture and Biology. 8(2):158-167.

Susanna TL. 2007. Cultivation of Chlorella vulgaris Using Plant-based and Animal waste-based Compost: A Comparison Study. Procedia Engin. 8(2016): 679-686. http://dx.doi.org/10.1016/j.proeng.20 16.06 .551

Utomo. 1996. Effect of iron on growth and lipid accumulation in Chlorella vulgaris, Bioresour. Technol. 99: 4717- 4722. London.

Xin, 2010. Global biodiversity patterns of benthic marine algae. Ecol. 87(10): 2479-2488.

Yap PY, Jain A and Trau D. 2018. Determination of biomass in Spirulina cultures by photopette. Life Science Application Note 050. Version 1: 1-3.

Zarrouk C. 1966. Contribution a l'etude d'une cyanophycee. Influence de divers facteurs physiques et chimiques sur la croissance et la photosynthese de Spirulina maxima (Setch. et Gardner). Geitler [Ph.D. thesis], University of Paris, Paris, France, 1966

Zhu. 2008. Spirulina as a livestock supplement and animal feed. Review Article. J. Anim. Physiol. Anim. Nutr. 97: 615-623. 